\title{
ANCIENT ATHENIAN DIRECT DEMOCRACY: ANY LIBERAL DEMOCRATIC POTENTIAL?
}

\author{
Antik Atina Doğrudan Demokrasisi: \\ Liberal Demokratik Bir Potansiyele Sahip miydi?
}

\section{Yavuz Selim ALKAN*}

\section{Keywords: \\ Direct Democracy, \\ Ancient Athenian \\ Democracy, Liberal \\ Democracy, \\ Liberalism.}

JEL Codes:

B20, H70, Y8

Anahtar Kelimeler:

Doğrudan Demokrasi,

Antik Atina

Demokrasisi, Liberal

Demokrasi,

Liberalizm.

JEL Kodları:

B20, H70, Y8

\begin{abstract}
This study aims to assess the claims whether or not the direct democracy in ancient Athens can be properly regarded as a liberal democracy or had the potentials to evolve into a liberal democratic regime. For this purpose, firstly, a brief examination of liberal democracy is provided focusing on the basic tenets of liberalism; namely individualism, the limited conceptualisation of the state, negative freedom, and rights. Then, the basic principles and ideals of ancient Athenian direct democracy are briefly analysed to unveil its liberal democratic potential. The main argument raised in this study is that some essential characteristics of the Athenian version of direct democracy, viz. protecting the individual from the state interference and having several immunities to protect the negative liberties of citizens, were like liberal values and the indicators of the political regime's liberal potential. It is also argued that it is much more persuasive to argue that ancient Athenian direct democracy had liberal democratic potentials because it facilitated the extension of core liberties than the claim that Athenian democracy could have evolved into a more liberal democratic political regime if historical conditions had been different. Methodologically, this is a qualitative study in analytic and normative political-philosophical theory.
\end{abstract}

\section{$\ddot{\mathrm{O} z}$}

Bu çalışma, antik Atina doğrudan demokrasisinin bir liberal demokrasi olarak görülüp görülemeyeceği veya liberal bir siyasal rejime evrilme potansiyeline sahip olup olmadığı yönündeki iddiaları değerlendirmeyi amaçlamaktadır. $\mathrm{Bu}$ maksatla, önce liberalizmin bireycilik, sınırlı devlet, negatif özgürlük ve haklar gibi temel niteliklerine odaklanarak kısa bir analizi sunulmuştur. Daha sonra antik Atina doğrudan demokrasisinin temel prensipleri ve idealleri onun liberal demokratik potansiyelini ortaya çıkarmak amacıyla kısaca analiz edilmiştir. $\mathrm{Bu}$ çalışmada ortaya konulan ana argüman, Atina doğrudan demokrasisinin bireyi devlet müdahalesinden koruma ve vatandaşların negatif özgürlüklerini korumak için sahip olduğu çeşitli bağışıklıklar gibi bazı temel karakteristikleri bir nevi liberal değerlerdir ve Atina politik rejiminin liberal bir potansiyel taşıdığının göstergeleridir. Ayrıca çalışmada, antik Atina doğrudan demokrasisinin temel özgürlükleri genişletmeyi sağladığı için liberal demokratik bir potansiyele sahip olduğunu iddia etmenin, eğer tarihsel koşullar farklı olsaydı Atina demokrasisi daha liberal demokratik bir siyasal rejime evrilebilirdi savından daha ikna edici bir argüman olduğu savunulmuştur. Metodolojik olarak bu çalışma, analitik ve normatif siyaset felsefesi teorisi içerisinde bir nitel çalışmadır.

\footnotetext{
* Asst. Prof. Dr., Akdeniz University, Faculty of Economics and Administrative Sciences, Department of Political Science and Public Administration, yavuzselimalkan@akdeniz.edu.tr, ORCID: 0000-0002-52115809
} 


\section{Introduction}

Democracy has ancient roots dating back to Ancient Greece while liberalism made an appearance in political history in the seventeenth century. Even though democracy is an older concept than liberalism, democracy disappeared on the political stage of Europe for centuries. In other words, as Bhikhu Parekh (1993, p. 157) notes, liberalism appeared long before the modern idea of democracy. This historical reality calls to mind a question: why did democracy come back?

There might be two plausible answers to this question: The first answer is that democracy was reapplied as a more viable option to address the growing demand for universal suffrage and to adapt to the new political, social and economic structure that emerged in the seventeenth and eighteenth centuries in Europe. The "dissolution of feudal society, the emergence of the nationstate, and the first intimations of popular power" along with the ideals that flourished in the French and American Revolutions, notably liberty and equality, attacked the "traditional notions of authority and obligation" (Levine, 1981, p. 14). This resulted in altering the legitimacy of the authority from the king or monarch to the people (see, Minogue, 2000, p. 207). With the aforementioned political (social and economic) transformation process liberals, who largely established their philosophical and political stance upon the desire to limit the political authorities, diverted their attention to rest the legitimacy of authority on the people. They started to consider the merits of democracy as a feasible option to address the growing demand for participation and self-rule. The second possible answer is that regardless of the aforementioned historical developments, liberalism's core essentials; such as individual liberty, limited state, state neutrality, the separation between the private and public spheres, the rule of law, etc., themselves include the essentials of democracy. This approach is also a challenge to the idea that a liberal regime can be non-democratic (in terms of the election of the government) as long as the authority is limited.

No matter what the reasons for the merger of liberalism and democracy were, this new model of democracy was quite different from its pure version in ancient Greece. While the ancient model of democracy was built upon direct democratic participation in the decisionmaking process, due to the growing population and the increased size of the political units in the modern era, liberal democracy has relied on "elected representation in the legislature" (Plattner, 1998, p. 174). It is argued by some that "modern liberal democracy from the outset was inclined to minimize the direct political role of the people" (Plattner, 1998, p. 174). Besides, contrary to its ancient counterpart, modern liberal democracy is based on the system of "check and balances" developed especially by the Framers (the founding fathers of the United States) (Plattner, 1998, p. 174) $)^{1}$. In other words, modern democracy is built upon the idea that the ruling power/government/state should be limited in order not to impose any particular worldview upon individuals. Thus, the person in a liberal democratic regime can freely choose any worldview or understanding of good among many different alternatives to lead a good life.

This new model, on the other hand, was "much more egalitarian than was ancient democracy" because women, slaves, and aliens were excluded from participation in Athenian

\footnotetext{
${ }^{1}$ It should be noted that referring to Plattner's two bases of liberal democracy does not mean that I mean specific ostensibly liberal-democratic regime. In this part, I aim to refer to liberal democracy as a general concept despite the fact that American liberalism/liberal democracy has mostly dominated discussions over the bases of liberal democracy.
} 
democracy and also there were restrictions on citizenship in terms of property ownership. In other words, "preliberal democracy, the direct democracy of the ancient city, was not based on any concept of the fundamental, natural equality of all human beings" (Plattner, 1998, p. 175). ${ }^{2}$

In short, even though classical liberalism did not initially embrace popular power or popular sovereignty as the source and justification of political authority, due to both the aforementioned historical developments and the characteristics of liberalism itself, the underlying principles of liberalism have combined with democracy. Even, among the different types and understandings of democracy, liberal democracy has been widely regarded as one of the most "feasible and attractive" (Levine, 1981, p. 137) forms of democracy in modern times. Francis Fukuyama $(1989,1992)$, for instance, announced the collapse of the communist bloc as the "end of history" and championed liberal democracy and market economy as the final (and more viable) form of organization of political and economic structure.

However, despite its acclaimed hegemony over the other possible forms of democracy, there has also been a growing reservation among several scholars about the deficiencies of liberal democracy. It has been claimed that liberal democracy and its prevalent decision-making form, namely representative democracy, are unable to respond to the increasing demand for more direct participation in decision-making mechanisms and, more importantly, their institutional structure is inadequate to address two recent political and sociological phenomena: multiculturalism and the politics of difference. The functions and institutions of liberal democracy have therefore been objected to by the supporters of direct (see Budge, 1996; Craig, Kreppel, and Kane, 2001; Dalton, 2004; Dalton, Burklin, and Drummond, 2001; Donovan and Karp, 2006; Gerret, 1997; Ober and Hedrick, 1996; Inglehart, 1990; Lupia and Matsusaka, 2004; Maskivker, 2010; Norris, 1999; Ober, 2000; Ober and Leininger, 2015), deliberative (Benhabib, 1996; Bohman, 1998; Dryzek, 2000; Gutmann and Thompson, 2004; Habermas, 1996; Macedo, 1999), and agonistic democracy (Laclau and Mouffe, 1985; Mouffe, 1999). ${ }^{3}$

Despite the essential theoretically, ontologically, and normatively based differences among those three critical perspectives on representative democracy, there is a prevailing consensus among those perspectives on the idea that liberal and/or representative democracy is in a crisis and it cannot deal effectively with the challenges resulted mainly from the increasing ethnoreligious pluralism and multiculturalism in the Western world. This crisis should therefore be overcome by designing a more inclusive model of democracy that takes differences and the pluralism of values into consideration and stands for a decision-making mechanism based on more direct citizen involvement and deliberation rather than taking representative democracy

\footnotetext{
${ }^{2}$ However, this does not necessarily mean that either earlier proponents of classical liberalism or liberal democrats were initially egalitarian in terms of suffrage. For instance, John Stuart Mill, as one of the founders of liberalism, "had serious reservations about the basic principle of universal suffrage, ie oneman-one-vote" (Chaudhuri, 1985, p. 958, see also Held, 1996, p. 109; Plattner, 1998, p. 175). On the other hand, it should be noted that the idea of universal suffrage is a recent phenomenon. Therefore, blaming the earlier leading figures in classical liberalism for not being democrat due to their exclusivist approach to universal suffrage seems somewhat anachronistic.

${ }^{3}$ In recent years, a rich empirical literature has emerged aiming to answer who supports participatory forms of democracy and to explain political behaviours of those individuals and groups (see Bowler, Donovan, and Karp, 2007; Donovan and Karp, 2006; Gilljam, Pesonen, and Listhaug, 1998; Hibbing and Theiss-Morse, 2002; Şener and Çağlar, 2020).
} 
for granted. This inevitably increased scholarly attention on direct democracy and also its pure form conducted in ancient Greek democracy, particularly in Athens. ${ }^{4}$

Both similarities and differences between liberal democracy and ancient Athenian democracy, liberal democracy's acclaimed hegemonic position, and growing recent critical stance towards liberal democracy from the proponents of direct democracy have spurred academic interest in democracy's Athenian form. A relatively small portion of this interest has specifically focused on a question of whether the Athenian political regime had some affinities with the modern liberal democracy or some potential to evolve into a liberal-like regime. This interest might have two different but interrelated aims: the first one is related to the hegemonic position of liberalism, namely, it is aimed to show that even some basic characteristics of the ancient democracy were based on liberal values or at least had liberal potential. The second aim might be that unveiling the liberal characteristics or the potential of the ancient democracy might be used as a convincing argument against the critics of liberal and/or representative democracy who point to the need to use the tools of direct democracy in modern decisionmaking mechanisms to deal with the aforementioned crisis. No matter which aims the scholars choose, especially with Josiah Ober $(2000,2008,2017,2019)$, there has been an interest in the scholarly literature to indicate that ancient Athenian direct democracy has some liberal potential.

In this study, the aforementioned claim that the political system in ancient Athens can be properly regarded as liberal or had liberal democratic potentials will be examined. To that end, first, the chief theoretical presuppositions and premises of liberalism and liberal democracy are elucidated by focusing on the similarities and differences between modern liberal democracy and the Athenian direct democracy. Given that there is not only one but divergent liberal theories, such as political and comprehensive liberalism, and debates over the essentials of liberal democracy are too wide to analyze comprehensively in nature hence, liberal democracy is examined with reference to the classical liberal perspective. In this regard, I aim to analyze the basic tenets of liberalism concerning its core understanding of democracy, individualism, the limited conceptualisation of the state, negative freedom, and rights. Then, a brief examination of the essential characteristics of the Athenian direct democracy will be provided with the aim of evaluating the claim that it was based on liberal-like values or at least had liberal democratic potentials to evolve into a liberal regime.

Methodologically, this is a qualitative study in analytic and normative politicalphilosophical theory. It should be noted that ethics committee approval and/or legal/special permission are not required in this study and this study complies with research and publication ethics.

\footnotetext{
${ }^{4}$ Notably, following Julia Maskivker, while analysing Greek democracy, I will refer exclusively to Athenian democracy, although there were many other city-states in Ancient Greece since not all of the other city-states were democratic. Furthermore, my comments throughout will be confined to Athenian democracy in the $5^{\text {th }}$ and $4^{\text {th }}$ centuries (between the reforms of Solon c. 590 BC and the victory of the Macedonians over Athens in $322 \mathrm{BC}$ ). Moreover, two moments of the oligarchic rule will also be ignored: the regime of the Four Hundred (411-10) and the Tyranny of the Thirty (404-403). See Maskivker (2010, p. 868).
} 


\section{Liberalism and Liberal Democracy: A Brief Overview}

When liberal is an adjective "applied to systems of government [it] classically implies a concern with individual freedoms that centers on the need to limit the power and authority of government" (Holden, 1988, p. 12). In other words, liberal as an adjective in the phrase of liberal democracy denotes "not to the matter of who rules but to the matter of how that rule is exercised" (Plattner, 1998, p. 172). For Parekh (1993, p. 160), liberal democracy means "liberalized democracy: that is, democracy defined and structured within the limits set by liberalism". It refers to the idea that government should be "limited in its powers and its modes of acting" (Plattner, 1998, p. 172; see also Holden, 1988). Plattner (1999, p. 122) also argues that "there does not seem to be any reason in principle why such a government must be chosen by the people. A constitutional government of one man or of a few could rule in such a way as to protect the rights of individuals".

In this regard, contrary to the Ancient democracy, it is argued that, according to classical liberalism, the point is not the source of authority for the government but to limit its role and to create a private sphere for the individual which is free from any interference of others (either the state or the other individuals in a society). That is to say, the authority of a king or a monarch is legitimate provided that its role is limited in terms of not interfering with the private sphere of the individual where he or she freely seeks the pursuit of happiness. As Michael Mc Donald (1991, p. 222) points out, liberalism identifies "a domain within which the individual is to be sovereign".

It is, however, highly contestable to argue that a liberal regime can be non-democratic as long as the authority of government is limited. This idea has also the potential to neglect one of the basic elements of democracy entrenched in liberalism. The ideas of negative liberty, the individual as the bearer of inalienable rights, universal suffrage, and universal citizenship require altering the legitimacy of authority from the king or monarch to the "people". In addition, the idea of John Locke, who was one of the founders of liberal thought, that the legitimacy of authority derives from the consent of the people (see Plattner, 1999, pp. 123-124) can also be seen as another reason for arguing that liberalism itself includes some basic elements of democracy. For instance, Plattner (1999) notes that:

"First, the spread of liberal ideas of the natural freedom and equality of all human beings doomed any special and substantial privileges enjoyed on the basis of heredity. Second, these same liberal ideas eventually undermined any effort to exclude people from political participation on the basis of such factors as race, religion, or sex. Third, the attempt to limit the franchise on the basis of property qualifications was the greatest potential obstacle to the democratization of liberalism, because it could claim some basis in the sacredness of private property endorsed by liberalism itself"' (p. 130).

It may be inferred from Plattner's argument that even though historical transformations have been regarded as the impetus for the merger of liberalism and democracy, the basic principles and ideals of liberalism (i.e. priority of liberty) themselves triggered the aforementioned historical transformations. Democracy in liberalism, unlike its ancient role and due to the liberal idée fixe, viz. "limited authority", appeared in the scene of history by metamorphosing into a new form. Fears about the tyranny of the majority and the idea of the impracticality of direct democracy, liberals invented representative democracy as a new form of 
democracy that was viewed as the most appropriate way of reaching the legitimate authority resting upon the people's consent.

Despite its many varieties, liberalism has a core doctrine premised upon the assumption that "individuals are mostly motivated by self-interest rather than any conception of the common good, and that themselves are the best judges of what this self-interest entails" (Dryzek, 2000, p. 9). As will be shown below, in Ancient democracy, the polis comes before the individual, namely, the common good overrides self-interest. This understanding of the individual is the essential reason why liberals aspire to limit the role of the state, "A fear that self-interested individuals, even if they are in the majority, may turn public power to private advantage" led liberals to establish "a set of constitutional rights to protect individuals against the government, and against each other" (Dryzek, 2000, p. 9) ${ }^{5}$. This approach reminds us of Lord Acton's renowned aphorism that "power tends to corrupt and absolute power corrupts absolutely" (Rogow and Lasswell, 1963). The core ideal of liberalism as the limitation of absolute power reflects the spirit that Lord Acton's aphorism has (Şahin, 2008).

As Touraine posits, talking about a "non/anti-liberal" democracy is a contradictory statement since it denotes an authoritarian regime. In other words, there is not any "democracy" that is not "liberal"; however, there are a lot of "liberal regimes" which are not "democratic" (Touraine, 2011, p. 71) ${ }^{6}$. Liberalism, in a nutshell, has developed a novel understanding of politics which focuses upon "the activities of private individuals in their pursuit of idiosyncratic interest and the protection by the state of their constitutional and legal rights to life, liberty, and property" (Axtmann, 1996, p. 46) 7 . In a similar vein, as Jeremy Waldron (1987, p. 128) puts it while talking about liberalism we can refer to a common view underlying "many of the most characteristic and distinctive liberal positions" that "liberals are committed to a conception of freedom and of respect for the capacities and the agency of individual men and women", and that these promises create "a requirement that all aspects of the social should either be made acceptable or be capable of being made acceptable to every last individual".

What does the limited role of the state mean? What is the rationale for emphasising the protection of the private sphere? How can the interests and preferences of the people be aggregated to shape the polity? The following section addresses these questions to sketch the core normative ideals of liberalism.

\footnotetext{
${ }^{5}$ I disagree with Dryzek insofar as in my view his empirical statement about motivation is unnecessary and inaccurate with regard to liberalism's commitments. As will be examined later in this part, liberalism does not necessarily ignore "the common good". The second part of his sentence is more accurate.

${ }^{6}$ It seems worthy to mention that Touraine cannot be accepted as a vigorous advocate of liberalism and liberal democracy. On the contrary, he presents a critique of liberalism and its economic capitalism in his book with reference to post-modern critiques of it.

${ }^{7}$ From this perspective, liberal democrats differ from Hobbes in their understanding of sovereignty. Hobbes mainly dealt with the need for and existence of sovereignty without mentioning the idea that a sovereign should be responsive to individuals' interests. Rather, liberal democracy calls for "not just any sovereign, but for a sovereign continually responsive to individuals' interests" (Levine, 1981, p. 14).
} 


\subsection{Individualism}

The core assumptions and arguments of liberalism have been built upon the idea of individualism. The basic liberal thesis holds that individuals ought to be the "authors of their own lives" (Axtmann, 1996, p. 6), and thus they possess "capacities and interests of a nonpolitical nature which they (...) [are] at liberty to express and pursue without the state's interference" (Axtmann, 1996, p. 17). Besides being free from any interference of the state (or from the others in society), individuals are seen as "competitive", "atomistic" and "rational agents" who are pursuing their idiosyncratic interests, and also regarded as "by nature free and capable of forming, revising and pursuing her or his definition of the good" (Axtmann, 1996, p. 37). Thus, the role of the state should not be to "make citizens virtuous", it has to be neutral by not promoting any particular "virtue" and by not "punishing vice" (Axtmann, 1996, p. 5).

One may argue that the conceptualisation of atomistic individualism in liberalism designates a disconnected relationship between the individual and the community (see, Sandel, 1998; Walzer, 1990, pp. 20-21). According to Levine (1981, p. 45), for instance, such an atomistic conceptualisation of individualism denotes the idea that individuals are "independent of one another and of society, bearing only extrinsic relations to one another". The contact between the individuals in a society is "in no way constitutive of the individual's nature". In other saying, "society (...) is just a collection of (atomic) individuals".

However, it should be noted that arguing that liberalism is built upon an atomistic conceptualisation of individualism gets into a slight strawman of liberalism. Liberal views need not see individuals as competitive or atomistic, and even rational agents. For instance, John Stuart Mill plainly puts that the community/society has a powerful role in forming and moulding an individual's desires, needs, and so forth. Mill regarded personal relationships and families as certainly the site of politics (see Mann and Spinner-Halev, 2010). Basically, he was really worried about the ill effects of the sorts of forming/moulding going on in his day, but he was not necessarily against any form of societal forming/moulding though - there could be liberal institutions e.g. certain family forms, that could play a powerful role in the producing of liberal individuals.

\subsection{Negative Freedom}

Another significant tenet of liberalism that has taken its form within the framework of liberalism's understanding of individualism is freedom/liberty. Liberty provides the basis for the main role of the state assigned by liberalism. Liberalism has favoured "negative freedom". Negative freedom amounts to a view that "a person's liberty is simply the extent to which [s/]he can act unconstrained by literal obstruction or interference from others" (Waldron, 1987, p. 130; see also Mack and Gaus, 2004). In this perspective, Locke's arguments about consent, rights of the individuals, and the legitimacy of the government underlie the liberal idea of a minimal state that is inspired by the idea of negative liberty. According to Locke, (wo/)men possess "equal rights under the law of nature", thus a person's consent constitutes the legitimacy of the authority. In other words, the legitimacy of the authority in a liberal polity is derived from the consent of the people and the main (or limited) role of the government is only to protect "life, liberty, and property of the individual" (Axtmann, 1996, p. 17). In a similar vein to Locke, Mill argues that the state "should limit itself to the performance of two roles": "to prevent abuses of 
individual liberties" and "the enforcement of democratically established rules of conduct" (Bonanno, 2000, p. 309). This minimal understanding of the state inspired by the idea of leaving the individuals free in terms of their preferences and decisions amounts to the following roles in political and economic senses: politically, the role of the state needs to be "the guarantor of individual freedom and societal autonomy only" (Axtmann, 1996, p. 42), and economically, a "society's nightwatchman" or a "referee" "ensuring just that rules for regulating competition and organising cooperation" or "resolving disputes" exist and are abided with (Levine, 1981, p. 21). To put it briefly, as Touraine (2011, p. 79) argues, limiting the government is indispensable for the existence of democracy, thus we should advocate the liberal political system against authoritarian threats.

Assigning a limited role to the state has exacerbated debates among not only the opponents but also the proponents of liberalism over the (desired or disapproved) increasing role of the state in social and economic life. Unlike liberalism's exclusive emphasis on negative liberty, for instance, Thomas Hill Green points to the fact that if there is a "true freedom", it is "not merely the absence of restraint or compulsion"; rather, this negative understanding of liberty should be "complemented by a positive capacity of self-determination". In other words, the state needs to provide individuals with "certain conditions of life" for them to realise their capabilities (Axtmann, 1996, p. 39). It seems that Green assigns society (or the state) a role that is quite similar to the role of the welfare state which is expected to provide the individuals with "positive supports" to make them "free" (Şahin, 2008). In a similar vein to Green, some modern liberals, such as John Rawls, Ronald Dworkin, and Will Kymlicka, view freedom not as "negative freedom" about freedom from intervention, but as freedom as "autonomy" which denotes the idea that the individual as a rational agent can form, revise or leave his or her own good way of life. Therefore, this understanding of "autonomy" can only be realised provided that the individuals are equipped with certain conditions (viz. positive freedom) (Şahin, 2008).

Leaving aside the competing arguments regarding the role of the state particularly in economics (see Axtmann, 1996, p. 42; Bonanno, pp. 309-310, 315; Friedman, 1977, 1982), it is helpful to have a look at the criticisms directed at classical liberalism's negative conception of freedom by the republican tradition to grasp better the differences between modern and ancient democracies. To recapitulate from Friedrich Hayek's perspective, liberalism focuses primarily on "the protection to be left alone ('negative liberty') and the protection of the sphere within which individuals can act unobstructed by others, not with ensuring the rights to be involved defining and deciding public matters ('positive liberty')" (Axtmann, 1996, p. 38). However, republican theorists purport that the "opportunity to participate in the collective affairs of the political community will actually have a virtuous formative impact upon citizens" (Offe, 2011, p. 451). The republican tradition assigns positive freedom, namely "self determination through participation in public affairs" (Maskivker, 2010, p. 855) a constitutive role in the identity formation of the individual. In a nutshell, Thomas Christiano (1990, pp. 153-154) provides a concise analysis of "positive liberty arguments" noting that "participationists" view freedom as "self-development", thus each person should participate in shaping common activities on an equal basis. This sort of understanding of freedom views participation as the necessary precondition of "self-development" and claims that participation has an essential role in transforming and forming the individuals' character.

This view has similarities with the idea of citizenship in Ancient Athenian society which has roots in Aristotle's ideas. Hannah Arendt (and as an earlier example, Niccolò Machiavelli) 
can be seen as one of the prominent modern advocates of this tradition (Axtmann, 1996, p. 46). Put briefly, unlike liberalism's depiction of the citizen as the bearer of rights living in a society as being free from any interference, Arendt views citizenship "as an office and a responsibility" (Axtmann, 1996, p. 46) and labels it as "active citizenship" (Axtmann, 1996, p. 52) that requires "participation in discourses about "the good life" and the building of a world of common political institutions" (Axtmann, 1996, p. 53). It is clear that republican politics, like their Ancient counterparts in Athens, hold a view that "public virtues" are "best 'learned' through participation in the public sphere, whereas liberalism (...) tends to privilege the 'private' sphere of the family and formal education" (Axtmann, 1996, p. 72).

\subsection{Separation of Power, Constitutionalism, and the Rule of Law}

As will be mentioned below, while there is no separation between the powers in Ancient Athenian democracy, the limited state understanding of liberalism arising from the negative conception of freedom underlay the liberal ideals of separation of power, constitutionalism, and the rule of law. In modern times, especially during the establishment of the United States, the fears of the tyranny of majority expressed by Alexis de Tocqueville and James Madison resulted in developing the ideas of judicial review, divided representation (namely, separation of powers, inspired by Montesquieu), and the system of checks and balances between the three main branches of the government (the legislative, executive and judicial) to "curb such tendencies as much as possible" (Bellamy and Castiglione, 1997, p. 609). Therefore, constitutions, as the combination of "separation of powers, checks and balances, civil liberties, and civil rights" are designed to "protect against illegitimate political coercion against persons" (Warren, 1989, p. 511).

In his well-articulated argument, Axtmann (1996, p. 42) concisely notes that liberal constitutionalism seeks to "combine an endorsement of the coercive role of the state as the enforcer of civil peace and collectively binding decisions (the Hobbesian tradition)" with another crucial "endorsement of the right of protection of individuals and social groups against the agency of the state (the Lockean tradition)". In this sense, respect for the rule of law has been regarded as another device to protect individual freedom. The rule of law, as Hayek puts it, means that "government in all its actions is bound by rules fixed and announced beforehand" (Hutchinson and Monahan, 2001, p. 349 citing Hayek, 1946, p. 54). From this perspective, the rule of law has been premised upon the "ideal of limited government" (Hutchinson and Monahan, 2001, p. 343) and the courts (particularly the Supreme Court in the USA or the constitutional courts) have been regarded as "the guardians of the rule of law" (Hutchinson and Monahan, 2001, p. 348). In a nutshell, as Plattner points out (1999, p. 122) "liberalism entails a government that is limited by a constitution and by the rule of law".

\subsection{The Distinction between the Private and the Public Spheres}

How can a sphere for the individual which is free from any interference of others be created? To answer this question, liberals attempt to "establish a distinction between the public and the private aspects of a person's life — between those activities for which [s] he is accountable to society (those which are to be open to evaluation and criticism by others) and those that are not" (Waldron, 1987, p. 147). 
In this sense, Mill makes a distinction between the concepts of self-regarding conduct and other-regarding conduct to draw the line between the private and the public spheres. As Mill argues, conduct cannot be regarded as an object of legal regulation so long as it only involves the interests of those who participate in and choose to perform it (or so long as the activities of the individual are not harmful to others), (he called this self-regarding conduct). On the other hand, when it is other-regarding, conduct is a proper object of legal regulation only when it violates the rights of non-consenting others (or so long as the activities of the individual are harmful to others) (Nussbaum, 2010, p. 56). In other words, as Nussbaum deduces from Mill's distinction, people require "zones of freedom" around them to fulfill their potential and these zones should protect particular rights of "personal decision" and "association" (Nussbaum, 2010, p. 56). As she notes, the collective interest cannot always surpass individual entitlement and certain rights of people cannot be taken away by the judgments of a collectivity (Nussbaum, 2010, p. 60). Thus, "the private sphere" becomes a realm that is free from state interference and also the interference of others where the individual freely pursues her or his own means and ends. As Levine puts it, Mill's distinction "delimit[s] the respective scopes of the liberal and democratic components", in other words, only whatever falls within the public is "susceptible to democratic collective choice" (Levine, 1981, p. 112).

\subsection{Rights}

Finally, if the one way of protecting the individual from interference is distinguishing between the public and the private spheres, rights can be accepted as another fundamental source to which individuals appeal when asserting protection from the others in society and the state. Rights, as Levine (1981, pp. 124-125) notes, play a crucial role in much liberalism and liberal democracy in protecting the individual from "societal and state interference", in other words, in limiting "the power of the state" "by the rights of the individuals" (see also McDonald, 1991, p. 221). In liberal philosophy, it has often been supposed that individuals possess natural inalienable rights that society and the state must protect and maintain. This approach is largely derived from the Lockean idea of the social contract that attempts to clarify "how people created civil society to protect better their [natural] individual rights" (Hutchinson and Monahan, 2001, p. 347) by disposing of their "executive rights" (Axtmann, 1996, p. 16) to establish the state (or community) whose primary role is to protect the people's inalienable rights. Even though the list is exhaustive, these inalienable rights have been divided into two main categories by several scholars, such as Mill and Michael McDonald: "civil and political rights" (Levine, 1981, pp. 125-126; McDonald, 1991, pp. 221-222). However, with the growing demands for giving the state a more interventionist role in the economy and social life, "social rights" have been added to this list. In the late modern times, "cultural rights", "environmental rights", and "group rights" have also been added with the growing multiculturalism in the Western world and increasing environmental problems and climate change (see Erdoğan, 2011, pp. 180-181).

Rights in ancient Athenian democracy, not surprisingly, were different from the aforementioned modern understanding of rights, especially human rights, which refers to liberal ideals of negative freedom and the limited state. The individual in ancient democracy was not seen as the bearer of inalienable rights which should be protected against undemocratic state 
interference. The following section provides an examination of the basic principles and ideals of ancient Athenian direct democracy to determine whether it has liberal democratic potential.

\section{Ancient Athenian Direct Democracy: Liberal Democratic (or Otherwise)} Characteristics?

To briefly examine the differences between the ancient direct democracy and modern liberal democracy and to determine whether ancient Athenian direct democracy has liberal democratic potentials, we should first take a look at the original meaning of democracy and debates over changes of meaning attributed to it over time.

The original meaning of democracy in ancient Greece was a composite of and derived from two Greek words: demos which means the "people" (Kelsen, 1955, p. 1) or "the many" (Archibugi, 2005, p. 538), and kratos which means "rule" (Gordon, 1999, p. 60), "authority" (Gordon, 1999, p. 60) or "power" (Archibugi, 2005, p. 538). Thus, the original version of democracy coined in ancient Greece means "rule by the people" (Diamond, 1990, p. 49), "government by the people" (Kelsen, 1955, p. 2), or "the power of the people" (Ober, 2008, p. $3)$.

Even though the democracy's original version did not specifically refer to the majority rule, democracy has been generally associated with the majority rule in modern times. However, Ober (2008, p. 3) argues that the original meaning of democracy cannot merely be regarded as that of majority rule and it was "an intentionally pejorative diminution" alleged by Greek critics of democracy. Despite this, as he emphasises, the aforementioned reductive understanding of democracy has been adopted and has prevailed over time. In his extensive study concerning the original Greek meaning of democracy, he explores its meaning concerning the classical terminology for regime types. Ober $(2008$, p. 7) points out that, unlike monarchia and oligarchia, demokratia "is not in the first instance concerned with 'number", on the contrary, "the term demos refers to a collective body". In this sense, unlike arche, demokratia does not just mean "the power of demos", rather it means, "the empowered demos: the regime in which demos gains a collective capacity, to effect change in the public realm". His critical argument, which is contrary to the dominant assumptions of the original meaning of democracy, indicates that "the original meaning of democracy is the "collective capacity of a public to make good things happen in the public realm" and cannot be purely associated with "voting rules" and the "monopoly of offices" (Ober, 2008, p. 7). ${ }^{8}$

Ober's argument that the original meaning of democracy was not based on majority rule, voting, or monopoly offices is crucial. This is because even though the first recognised form of democracy in Ancient Greece was direct democracy; representative democracy, which mainly focuses on majority rule and voting, replaced it to some extent over time due to the common idea that direct democracy is "unable to function efficiently in large polities" (Dalton et al., 2001, p. 142; see Knopff, 1998, p. 684).

\footnotetext{
${ }^{8}$ Even though Ober's analysis sounds reasonable, his "to make good things happen" as an apposite element for anything but a Greek conception may be rejected. It may be better to substitute "to bring about its ends" for "to make good things happen" since the latter is a very instrumentalist conception of democracy as a collective means rather than as a fundamental value.
} 
According to Dalton et al. (2001, p. 142), direct democracy places "control of the government in the hands of the people". This succinct definition belies what is a somewhat more complex concept. Unpacking that concept somewhat, we may observe that the direct model of democracy is built on the premise that "citizens themselves can make wise decisions on political matters" (Dalton et al., 2001, p. 142) through a variety of decision processes, including "town meetings, recall elections, initiatives and various forms of referendums" (Lupia and Matsusaka, 2004, p. 465). The direct part of the concept provides that direct democracy refers to immediate citizen involvement in political processes (in the sense of an absence of any intermediaries).

This exactly defines the decision-making process that is taken to typify direct democracy in Ancient Athenian Greece. Athenian democracy can be regarded as the "first known example" and "much simpler form" of democracy (Pickles, 1970, p. 29). In many respects, the experience of the Athenians in their decision-making process may be regarded as a direct form of democracy when analysed concerning the aforementioned definition of Dalton et al. First and foremost, Athenian democracy can be described as direct democracy since citizens themselves made decisions on political matters without any intermediaries. There was the Assembly of Citizens in which citizens came together and made decisions on political matters via discussion and voting. ${ }^{9}$ Secondly, control of government was completely in the hands of the people. In other words, all decisions were made by the people directly, and "they had their own governments and constitutions and were not subject to the control [or] supervision of national government" (Pickles, 1970, p. 31). However, the assembly was not completely free to decide its agenda: there was another organ in the Athenian political system, called The Council. The Council was an "executive" or "steering committee" whose members were "chosen annually from a panel of citizens elected by the demes of Athens in proportion to their size" (Pickles, 1970, p. 31).

Leaving aside a comprehensive descriptive analysis of the political system and its organs in Athens, notable criticisms of direct democracy in Athens should be examined to evaluate its differences with the modern liberal democracy and its liberal democratic (or otherwise) characteristics. One of the main criticisms targeting Athenian democracy is that there were significant restrictions on citizenship in terms of age, gender, property ownership, and so forth. For instance, only native mature men were regarded as potential citizens/shareholders (Ober, 2000, p. 43), and women, slaves, and children were excluded from participation, namely, lawmaking and voting. Typically, a citizen in Athens was "a male over 18 years of age, legitimately born of an Athenian father and mother, whose neighbours had formally (by voting in the local assembly) accepted him as such", and finally "whose name (...) [should be included] (...) in his ancestral township or neighbourhood (...) citizen list" (Ober, 2000, p. 31). In this respect, citizenship in Athens can be defined as citizenship by "birth", "double native descent" and "autochthonous" (Ober, 2000, p. 51).

When the exclusion of women and slaves from political participation is analysed through the lens of modern democracy, it seems impossible to view the Athenian political system as democratic or liberal. However, some scholars argue that within the limits mentioned above, the

\footnotetext{
9 There were three main organs of government in the Athenian political system: The Assembly of Citizens, The Council and The Courts. The courts as the third organ of the Athenian system consisted of juries who were "chosen annually by lot to form popular law courts" (see Pickles, 1970, p. 35).
} 
Athenian political system could claim to be "a real democracy" (Pickles, 1970, p. 31): "Seen in its own context [not from the $20^{\text {th }}$-century democratic viewpoint], Greek democracy constituted so many islands of freedom in a surrounding world dominated by oligarchical or tyrannical forms of government" (Pickles, 1970, p. 40).

Is it totally convincing to refer to the context and island of freedom argument to categorise the Athenian democracy as democratic and liberal? I think, yes; but not enough: we need more convincing arguments to label the Athenian system as democratic and liberal despite the limitations placed on women, slaves, and many foreigners.

First and foremost, analysing the Athenian democratic system from a modern contemporary democratic viewpoint might lead to some misconceptions. As Pickles (1970, p. 33) points out, whereas modern democracy "starts from the individual, for whom politics is only one aspect of life", Athenian democracy "starts from the state and saw the individual's wellbeing as inseparable from that of the collective identity". In other words, the Athenian political experience represents an idea that the individual is fitted into a framework that is already there and the existing state is regarded as "providing the right, or the best way of life". In this sense, Pickles depicts individualism in the Athenian system as "static" while seeing the modern idea of individualism as "dynamic". In a similar vein, Ober (2000, p. 30) states that in Athens individual rights were accepted as "performative and contingent" rather than being seen as "natural, innate and inalienable". Ober depicts the Athenians, in a sense, as "rights pragmatists". Therefore, as Pickles (1970, pp. 33-34) notes, the concept of the individual in the Athenian system should not be analysed in light of the modern idea of individualism. It may be argued that Pickles identifies modern democratic individualism with liberal individualism, and so argues that regarding individualism or diversity as "not only normal and right but inevitable", and regarding "institutions as being required to provide for its free expression" are recent developments and modern ideas.

Secondly, according to Julia Maskivker (2010, p. 868), attempts in academia to make a distinction between the "modern socio-political landscape" and its equivalent in "Antiquity" have focused mainly on the distinction between negative and positive liberty. In this sense, similar to the brief examination on negative and positive liberty provided in the previous section of this study, Maskivker (2010, p. 855) points out that negative liberty is identified with "private immunities against interference" whereas positive liberty is identified with "the values of citizenship and collective decision making by all citizens in the Assembly". From this point of view, as Maskivker notes, Isaiah Berlin argues that "the ancient political world was characterised by positive liberty", whereas "modernity is characterised by negative liberty". Thus, this dichotomy leads one to see positive freedom (as "self determination through participation in public affairs") in tension with negative freedom ("which prioritizes the right to decide how one wishes to live over compulsory civic duties and self-sacrifice for the benefit of the community"). In other words, because women, slaves, and aliens were excluded from participation and (as it is argued that) there were no private immunities against interference in the Athenian political system, participatory democracy in Athens did not support the establishment of personal autonomy and liberty.

However, Ober (2000, p. 59) argues that in classical Athens "the practice of participatory democracy led to the development of a regime that was at once constitutional and fostered something like modern liberal values". In a similar vein, Maskivker (2010, p. 856) highlights 
the very relation between "the rule of law (facilitated by respect for individual rights and freedoms)" and "political autonomy" in classical Athens by representing how people in Athens sought to "protect the individual from state interference and to prevent tyranny of the majority". In a nutshell, it is argued that despite the limited conception of citizenship and exclusions from participation in Athens, there were also several immunities - at least in practice - to protect the negative liberties of citizens (also women and slaves). It will be useful to discuss the aforementioned immunities and extension of citizenship to analyse the liberal character of direct democracy in Athens.

In his extensive study, Ober (2000, p. 59) maintains that while "participation-rights were limited to NAMs [native adult men], certain negative liberties were (at least in legal practice) extended to all residents of the Athenian territory". The aforementioned extended participation rights and immunities may be summarised as follows: even though ownership of real property remained a monopoly of Athenian citizens, metics (resident aliens) were granted the right to own real estate and remission of the head-tax paid by resident foreigners (Ober, 2000, p. 59); many "nonêthic" Athenians were accepted as "the Athenians" despite being approved by special decree of the Assembly (Ober, 2000, p. 52) and even broader protections of children, women, slaves, and metics provided that they could not be struck with impunity (Ober, 2000, p. 50).

Similarly, Maskivker (2010, p. 856) points out that there was a tendency to extend "legal prerogatives" and "de facto freedoms to non-citizens". She also briefly argues for "the notion of a protected private sphere" in classical Athens which took the form of (i) private immunities against abuses on the part of the state; (ii) the individual freedom to lead a morally unconstrained life; and (iii) freedom of association and social interaction. In this context, she observes that the following immunities were extended to all residents besides citizens: even though women did not have political rights, they integrated into society by attending some social events and some kinds of economic interaction; women and slaves were protected under a norm against hubris (Maskivker, 2010, p. 861). Maskivker (2010, p. 862) concludes that "whether instrumental or not, the evolution of Athenian democracy prompted to the extension of prerogatives".

To sum up, Ober and Maskivker argue that although the aforementioned liberalisation and immunisation processes were not the result of any intentional act, but were rather an "unintended effect of ideological complexity" (Ober, 2000, p. 52); participatory democracy in Athens facilitated the extension of core liberties. In other words, the instruments in the Athenian system were not "to limit democracy but a precondition of its existence", and principally respect for the rule of law (not majority rule) in Athens "legitimated private autonomy- negative libertyand created the circumstances that made public autonomy-positive liberty-possible" (Maskivker, 2010, p. 867). The above-mentioned arguments raised by Ober and Maskivker sound reasonably serviceable to correlating the direct form of democracy in Athens and the modern democratic system. As Mogen H. Hansen (1996, p. 99) argues, the Athenian conception of liberty was, in some respects, similar to the idea of freedom in modern liberal democracies. Although accepting that the understanding of citizenship in Athens was highly exclusive compared to modern standards (Ober, 2000, p. 33), there are still reasons to believe that the Athenian political system was quite "inclusive" at least in practice. Moreover, it seems apposite to argue that Athenian democracy could evolve into a political system that might be called liberal in contemporary liberal perspectives. In other words, the trend towards a more liberal society "was 
slowed, or even reversed in the aftermath of the Athenian loss of formal independence to the autocratic Macedonians after 322 BC" (Ober, 2000, p. 41). ${ }^{10}$

\section{Conclusion}

In this study, claims regarding a resolution of whether or not the political system in ancient Athens is properly regarded as a liberal democratic regime is examined. To that end, first, a concise examination of liberal democracy, emphasizing the basic tenets of liberalism; namely individualism, the limited conceptualisation of the state, negative freedom, and rights have been provided. Second, a brief analysis of ancient Athenian direct democracy has been undertaken in light of the aforementioned basic tenets and principles of liberalism and liberal democracy.

It is initially argued that some historical, political, and economic transformations urged liberals to combine one of the core arguments, viz. the desire to limit the political authorities, with democracy to address the growing demand for participation and self-rule. However, it is also pointed out that the reciprocal interaction between the historical transformations and the essential liberal ideals should not be overlooked: one of the basic principles and ideals of liberalism examined in this study are democratic and they themselves triggered the aforementioned historical transformations. In other words, liberalism is itself a democratic theory and worldview. Detaching the core liberal values and normative principles from the democratic features and values embedded in liberalism carries a potential risk of rendering liberalism a contradictory, incoherent, and inconsistent theory and liberal democracy a descriptive and value-free account of democracy. This also makes the aim of revealing the liberal potential of the ancient Athenian direct democracy a meaningless and vain attempt, because the Athenian regime did not undergo the aforementioned historical transformations.

As a result of the examination of the arguments raised especially by Ober and Maskivker that the ancient Athenian democracy had some liberal-like attributes, it has been then argued that their claims are coherent and consistent. The Athenian version of direct democracy included some basic characteristics, viz. protecting the individual from state interference, several immunities to protect the negative liberties of citizens, etc. something like liberal values. In other words, the democratic political regime in ancient Athens had some resemblances with a constitutional democratic political system based on modern liberal values. Ancient Athenian democracy, however, was not a liberal democracy or its political regime was not entirely liberal. Some essential differences between the two are readily obvious: As shown in this study, there were restrictions on citizenship and women, slaves, and children were excluded from political participation in ancient Athens; individualism in the Athenian political system was "static"; individual rights were regarded as "performative and contingent"; there were no separation of powers, the rule of law, checks and balances; and the ancient political system was characterised by positive liberty.

\footnotetext{
${ }^{10}$ I would like to thank the unnamed referee for reminding me of and pointing out that Thucydides' History of the Peloponnesian War, particularly Pericles' Funeral Oration can be accepted as an emblematic example of the presence of negative liberty and toleration in ancient Athens (see Kagan, 1991).
} 
Liberalism, however, places the person/individual at the center of its theory. The person is regarded as inherently valuable in liberal theory because she is naturally good, rational, and can freely make choices. For a person to live a valuable life, she must be able to make rational and free choices to maximize her self-interest; independent from any external obstacle, coercion and pressure, especially coming from the state. The person is motivated and acts only by her own personal interest, not to realize a certain social good or interest. What makes the individual free is her own freely chosen life/style and the pursuit of happiness. Genuine liberty of the person is guaranteed when equal political participation is ensured, liberty is defined in negative terms, the private sphere of the individual is protected, and the state is minimal and neutral: the state should be neutral towards different understandings of good life and worldviews in society and should not impose any of them upon the persons.

The aforementioned historical conditions-related argument seems to work much better here in a different way. The aforementioned non-democratic or non-liberal features of ancient Athenian direct democracy should not be analysed through the lens of modern democracy; they should rather be evaluated within its own historical, social, or political conditions of ancient time. It is, however, much more convincing to argue that participatory democracy in ancient Athens has liberal democratic potentials since it facilitated the extension of core liberties than the idea that Athenian democracy could have evolved into a more liberal democratic political system if historical conditions had been different. The next justification can be labeled as unfounded and indefensible since it is based on speculative and hypothetical reasoning about the past (and the possible future).

As Pickles (1970, p. 41) notes, "although Greek democracy disappeared, Greek thought survived", and "all of us (...) have been influenced by it, by the critics of Greek democracy as well as by its defenders". This study can therefore provide ground for further research on the relationship and tension between liberalism and ancient Athenian direct democracy concerning equality, liberty, the role of the state.

\section{Researchers' Contribution Rate Statement:}

I am a single author of this paper. My contribution is $100 \%$.

\section{Conflict of Interest Statement:}

There is no potential conflict of interest in this study. 


\section{References}

Archibugi, D. (2005). The language of democracy: Vernacular or esperanto? A comparison between the multiculturalist and cosmopolitan perspectives. Political Studies, 53(3), 537-555. https://doi.org/10.1111/j.1467-9248.2005.00543.x

Axtmann, R. (1996). Liberal democracy into the twenty-first century: Globalization, integration and the nation-state. Manchester: Manchester University Press.

Bellamy R. and Castiglione, D. (1997). Constitutionalism and democracy - The political theory and the American constitution. British Journal of Political Science, 27, 595-618. https://doi.org/10.1017/S0007123497000288

Benhabib, S. (1996). Toward a deliberative model of democratic legitimacy. In S. Benhabib (Ed.), Democracy and difference: Contesting the boundaries of the political (pp. 67-94). Princeton, N. J.: Princeton University Press.

Bohman, J. (1998). Survey article: The coming of age of deliberative democracy. The Journal of Political Philosophy, 6(4), 400-425. https://doi.org/10.1111/1467-9760.00061

Bonanno, A. (2000). The crisis of representation: The limits of liberal democracy in the global era. Journal of Rural Studies, 16(3), 305-323. https://doi.org/10.1016/S0743-0167(99)00064-9

Bowler, S., Donovan, T. and Karp, J. A. (2007). Enraged or engaged? Preferences for direct citizen participation in affluent democracies. Political Research Quarterly, 60(3), 351-362. https://doi.org/10.1177/1065912907304108

Budge, I. (1996). The new challenge of direct democracy. Cambridge: Polity Press.

Chaudhuri, M. D. (1985). On the political structure of a liberal democracy. Economic and Political Weekly, 20(22), 958-959. Retrieved from https://www.jstor.org/

Christiano, T. (1990). Freedom, consensus, and equality in collective decision making. Ethics 101(1), 151-181. Retrieved from https://www.jstor.org/

Craig, S., Kreppel, A. and Kane, J. (2001). Public opinion and support for direct democracy: A grassroots perspective. In M. Mendelsohn and A. Parkin (Ed.), Referendum democracy: Citizens, elites and deliberation in referendum campaigns (pp. 25-46). New York: Palgrave.

Dalton, R. J. (2004). Democratic challenges, democratic choices: The erosion of political support in advanced democracies. New York: Oxford University Press.

Dalton, R. J., Burklin W. P. and Drummond, A. (2001). Public opinion and direct democracy. Journal of Democracy, 12(4), 141-153. https://doi:10.1353/jod.2001.0066

Diamond, L. J. (1990). Three paradoxes of democracy. Journal of Democracy, 1(3), 48-60. https://doi:10.1353/jod.1990.0047

Donovan, T. and Karp, J. A. (2006). Popular support for direct democracy. Party Politics, 12(5), 671-688. https://doi.org/10.1177/1354068806066793

Dryzek, J. S. (2000). Deliberative democracy and beyond: Liberals, critics, contestations. New York: Oxford University Press.

Erdoğan, M. (2011). Insan haklarl teorisi ve hukuku [Theory and law of human rights]. Ankara: Orion.

Friedman, M. (1977). The future of capitalism. California: Pepperdine University.

Friedman, M. (1982). Capitalism and freedom. Chicago: The University of Chicago Press.

Fukuyama, F. (1989). The end of history. The National Interest, 16, 3-18. Retrieved from https://www.jstor.org/

Fukuyama, F. (1992). The end of history and the last man. New York: The Free Press.

Gerret, E. (1997). Who directs direct democracy. University of Chicago Law School Roundtable, 4(1), 1736. Retrieved from https://chicagounbound.uchicago.edu/ 
Gilljam, M., Pesonen, P. and Listhaug, O. (1998). The referendum in representative democracies. In A. T. Jenssen, P. Pesonen and M. Gilljam (Eds), To join or not to join: Three nordic referendums on membership in the European Union. Oslo: Scandinavian University Press.

Gordon, S. (1999). Controlling the state: Constitutionalism from Ancient Athens to today. Cambridge: Harvard University Press.

Gutmann, A. and Thompson, D. (2004). Why deliberative democracy? New Jersey: Princeton University Press.

Habermas, J. (1996). Between facts and norms: Contributions to a discourse theory of law and democracy. Cambridge: MIT Press.

Hansen, M. (1996). Ancient Athenian and the modern liberal view of liberty as a democratic ideal. In J. Ober and C. Hendrick (Eds.), Demokratia (pp. 91-104). New Jersey: Princeton University Press.

Held, D. (1996). Models of democracy. Stanford: Stanford University Press.

Hibbing, J. R. and Theiss-Morse, E. (2002). Stealth democracy: Americans' beliefs about how government should work. New York: Cambridge University Press.

Holden, B. (1988). Understanding liberal democracy. New Jersey: Philip Allan.

Hutchinson, A. C. and Monahan, P. (2001). Democracy and the rule of law. In D. Dyzenhaus and A. Ripstein (Eds.), Law and morality: Readings in legal philosophy. Toronto: University of Toronto Press.

Inglehart, R. (1990). Culture shift in advanced industrial society. New Jersey: Princeton University Press.

Kagan, D. (1991). Pericles of Athens and the birth of democracy. London: Secker \& Warburg.

Kelsen, H. (1955). Foundations of democracy. Ethics, 66(1), 1-101. Retrieved from https://www.jstor.org/

Knopff, R. (1998). Populism and the politics of rights: The dual attack on representative democracy. Canadian Journal of Political Science, 31(4), 683-705. Retrieved from https://www.jstor.org/

Laclau, E. and Mouffe, C. (1985). Hegemony and socialist strategy towards a radical democratic politics. London: Verso.

Leininger, A. (2015). Popular support for direct democracy in Europe. In ECPR (Ed.), What citizens want from democracy: Popular attitudes to existing political processes and their alternatives. Paper presented at the ECPR Joint Sessions. Retrieved from https://ecpr.eu/Events/Event/PaperDetails/23848

Levine, A. (1981). Liberal democracy: A critique of its theory. New York: Columbia University Press.

Lupia, A. and Matsusaka, J. G. (2004). Direct democracy: New approaches to old questions. Annual Review of Political Science, 7, 463-482. https//:doi:10.1146/annurev.polisci.7.012003.104730

Macedo, S. (1999). Deliberative politics essays on democracy and disagreement. New York: Oxford University Press.

Mack, E. and Gaus, G. F. (2004). Classical liberalism and libertarianism: The liberty tradition. In E. Mack and G. F. Gaus (Eds.), Handbook of political theory (pp. 115-130). London: Sage Publications.

Mann, H. and Spinner-Halev, J. (2010). John Stuart Mill's feminism: On progress, the state, and the path to justice. Polity, 42(2), 244-270. https://doi.org/10.1057/pol.2009.17

Maskivker, J. (2010). Participation and rights in Athenian democracy: A Habermasian approach. The European Legacy, 15(7), 855-870. https://doi.org/10.1080/10848770.2010.528902

McDonald, M. (1991). Should communities have rights? Reflections on liberal individualism. Canadian Law of Journal and Jurisprudence, 4(2), 217- 237. https://doi: 10.1017/S0841820900002915

Minogue, K. (2000). Democracy as a telos. In E. F. Paul, F. D. Miller and J. F. Paul (Eds.), Democracy (pp. 203-224). Cambridge: Cambridge University Press.

Mouffe, C. (1999). Deliberative democracy or agonistic pluralism. Social Research, 66(3), 745-758. Retrieved from https://www.jstor.org/ 
Norris, P. (1999). Critical citizens: Global support for democratic governance. New York: Oxford University Press.

Nussbaum, M. C. (2010). From disgust to humanity: Sexual orientation and constitutional law. New York: Oxford University Press.

Ober, J. (2000). Quasi-rights: Participatory citizenship and negative liberties in democratic Athens. In E. F. Paul, F. D. Miller and J. Paul (Eds.), Democracy (pp. 27-61). Cambridge: Cambridge University Press.

Ober, J. (2008). The original meaning of "democracy": Capacity to do things, not majority rule. Constellations, 15(1), 3-9. https://doi.org/10.1111/j.1467-8675.2008.00471.x

Ober, J. (2017). Demopolis: Democracy before liberalism in theory and practice. Cambridge: Cambridge University Press.

Ober, J. (2019). What did 'democracy' mean to Greek democrats? Philosophy and Public Issues/Filosophia E Questioni Pubbliche, 9(2), 73-82. Retrieved from http://fqp.luiss.it/

Ober, J. and Hedrick, C. (1996). Demokratia. New Jersey: Princeton University Press.

Offe, C. (2011). Crisis and innovation of liberal democracy: Can deliberation be institutionalised. Czech Sociological Review, 47(3), 447-472. Retrieved from https://www.jstor.org/

Parekh, B. (1993). The cultural particularity of liberal democracy. In D. Held (Ed.), Prospects for democracy: North, south, east, west (pp. 156-175). Cambridge: Polity Press.

Pickles, D. (1970), Democracy. London: BT Batsford Ltd.

Plattner, M. F. (1998). Liberalism and democracy: Can't have one without the other. Foreign Affairs, 77(2), 171-180. https://doi.org/10.2307/20048858

Plattner, M. F. (1999). From liberalism to liberal democracy. Journal of Democracy, 10(3), 121-134. https//:doi: 10.1353/jod.1999.0053

Rogow, A. A. and Lasswell, H. D. (1963). Power, corruption, and rectitude. New Jersey: Prentice-Hall.

Şahin, B. (2008). Liberal demokrasinin temelleri [The foundations of liberal democracy]. Demokrasi Platformu, 3(10). Retrieved from https://www.demokrasiplatformu.com/

Sandel, M. (1998). Liberalism and the limits of justice. Cambridge: Cambridge University Press.

Şener, T. and Çağlar, N. (2020). Genç seçmenlerin siyasete olan ilgileri ve siyasal katılım açısından kümelenmeleri üzerine bir araştırma [A research on young voters' interest in politics and their clustering in terms of political participation]. Nevşehir Hacı Bektaş Veli Üniversitesi SBE Dergisi, 10(2), 514-531. https://doi.org/10.30783/nevsosbilen.746432

Touraine, A. (2011). Demokrasi nedir? [What is democracy ?]. İstanbul: Yap1 Kredi Yayınları.

Waldron, J. (1987). Theoretical foundations of liberalism. The Philosophical Quarterly, 37(147), 127150. Retrieved from https://www.jstor.org/

Walzer, M. (1990). The communitarian critique of liberalism. Political Theory, 18(1), 6-23. Retrieved from https://www.jstor.org/

Warren, M. (1989). Liberal constitutionalism as ideology: Marx and Habermas. Political Theory, 17(4), 511-534. Retrieved from https://www.jstor.org/ 